Diabetologia $6,1-7(1970)$

\title{
ORIGINALS
}

\section{Insulin Levels in Thyrotoxicosis and Primary Myxoedema : Response to Intravenous Glucose and Glucagon}

\author{
Domentco Andreani, Guido Menzinger, Francesco Fallucca, Giuseppe Aliberti, Guido Tamburrano \\ and Cataldo Cassano
}

Istituto di II. Clinica Medica, Università degli Studi di Roma and Cattedra di Terapia Medica Sistematica, Università Cattolica del S. Cuore - Roma - Italy

Received: January 13, 1969

Summary. Glucose disappearance, insulin-like activity (ILA) and serum immunoreactive insulin (IRI) were studied after intravenous injection of glucose or glucagon in patients suffering from thyrotoxicosis or primary myxoedema. A group of normal subjects was also investigated. Glucose disappearance rate appeared to be normal in hyperthyroid, and markedly reduced in hypothyroid subjects. Fasting ILA levels were significantly higher than normal in myxoedema, and lower than normal in thyrotoxicosis. On the other hand, fasting IRI levels were higher than normal in myxoedema but normal in thyrotoxicosis. After glucose administration ILA in myxoedema remained at higher values than in thyrotoxicosis at any time of the study; in myxoedema, peak ILA levels were reached later than in thyrotoxicosis; peak IRI levels of similar magnitude were reached slightly earlier than normal in thyrotoxicosis, and later in myxoedema; in the latter condition, elevated. IRI levels were observed for a longer period than in either euthyroidism or hyperthyroidism. During this test the insulingogenic index showed only slight changes in normal and in thyrotoxic subjects, whereas it increased significantly up to $60 \mathrm{~min}$ in myxoedema. The data indicate that the reduced glucose utilization in hypothyroidism is not due to insulin deficiency, but rather to insulin resistance. It also seems possible that thyroid function influences the time of maximal insulin response to intravenous glucose administration. After glucagon injection, the increase in blood glucose was lower and shorter than normal in thyrotoxicosis; it was initially somewhat slower, but later higher and more sustained than normal, in myxoedema. The smaller increment in blood glucose in the former condition is probably connected with reduced glycogen stores. ILA response was very high and well sustained in myxoedema, whereas it was moderate and shortlasting in thyrotoxicosis. IRI response was higher than normal in hypothyroid. subjects, and lower than normal in thyrotoxic subjects. No difference in the time required for maximal response was observed among the three groups.

Taux d'insuline dans la thyrotoxicose ei le myxoedème primaire: Réponse au glucose et au glucagon intraveineux

Résumé. La disparition du glucose, l'activité insulinique (ILA) et l'insuline immunoréactive (IRI) du sérum ont été étudiées après injection intraveineuse de glucose et de glucagon chez des malades affectés de thyréotoxicose ou de myxoedème primaire de l'adulte. Un groupe de sujets témoins a été également étudié. La vitesse de disparition du glucose était normale chez les hyperthyroïdiens et remarquablement réduite chez les myxoedémateux. Les niveaux d'ILA à jeun étaient beaucoup plus élevés chez les myxoedémateux et plus bas chez les hyperthyroïdiens par comparaison avec les sujets normaux. D'autre part les niveaux d'IRI à jeun étaient plus élevés chez les hypothyroïdiens, mais étaient normaux chez les hyperthyroïdiens. Après l'administration de glucose, l'activité insulin- ique resta à des valeurs plus élevées chez les hypothyroïdiens que chez les hyperthyroĩdiens pendantl'épreuve. Chez les myxoedémateux les taux maximum d'ILA étaient atteints plus tard que chez les hyperthyroïdiens. Des taux maximum d'IRI, de même grandeur, étaient obtenus un peu plus rapidement dans l'hyperthyroïdie et plus lentement dans l'hypothyroïdie par comparaison avec l'état normal; chez les myxoedémateux dos taux élevós d'IRI ont été observés plus longtemps que chez les normaux et les thyréotoxicosiques. Pendant l'épreuve l'index insulinogénique montra seulement de légères modifica. tions chez les normaux et les hyperthyroïdiens tandis qu'il augmenta significativement à 60 min chez les myxoedémateux. Les résultats semblent indiquer que l'utilisation réduite du glucose dans le myxoedème n'est pas due à une déficience en insuline, mais plutôt à la résistance à l'insuline. Il semble également possible que la fonction thyroïdienne influence le temps de réponse maximale de l'insuline à l'administration intraveineuse de glucose. Après injection de glucagon l'augmentation de la glycémie dans l'hyperthyroidie était réduite; dans le myxoedème au début elle était plus lente, mais plus tard très élevée et soutenue. La fugace augmentation glycémique après glucagon dans l'hyperthyroïdie est probablement liée aux réserves réduites de glycogène. La réponse de l'ILA était élevée et prolongée dans le myxoedème, tandis qu'elle était modérée et brève dans la thyréotoxicose. La réponse de l'IRI était plus élevée que normalement chez les sujets hypothyroïdiens, et plus basse chez les hyperthyroïdiens. En ce qui concerne le temps nécessaire pour obtenir la réponse maximale, aucune différence n'était observée entre les trois groupes.

Insulinspiegel bei Thyreotoxikose und primärem $M y x$ ödem: Verhalten nach intravenösen Gaben von Glucose und Glucagon

Zusammenfassung. Die Glucoseaufnahme, die Insulinähnliche Aktivität (ILA) und das Immunoreaktive Insulin (IRI) im Serum wurden bei Patienten mit Thyreotoxikose oder primärem Myxödem nach intravenösen Gaben von Glucose oder Glucagon untersucht. Die gleichen Untersuchungen wurden bei einem. Vergleichskollektiv durchgeführt. Bei Patienten mit Schilddrüsenüberfunktion fand sich eine normale, bei solchen mit Unterfunktion eine deutlich erniedrigte Glucoseaufnahme. Die NüchternILA-Spiegel waren bei Myxödem signifikant erhöht, bei Hyperthyreose niedriger als normal. Andererseits lagen die Nüchtern-IRI-Spiegel bei Myxödem über den Normalwerten und bei Hyperthyreose im Normbereich. Nach Glucosezufuhr überstiegen die ILA Werte zu allen Untersuchungszeitpunkten bei Hypothyreose die bei Hyperthyreose. Der Maximalwert für die ILA wurde bei Myxödem später als bei Thyreotoxikose erreicht. IRI-Höchstwerte von ähnlichem Ausmaß wurden bei Hyperthyreose etwas früher und bei Myxödem etwas später als normal erreicht. Die Erhöhung der IRI Werte hielt bei Hypo- 
thyreose länger als bei Euthyreose oder Hyperthyreose an. Während dieser Glucose-Belastung war der Insulinogenic Index bei Normalpersonen und Patienten mit Hyper. thyreose nur leicht verändert, während er bei MyxödemKranken bis $60 \mathrm{~min}$ signifikant erhöht war. Die Ergebnisse deuten darauf hin, daß die verringerte Glucoseaufnahme bei Hypothyreose nicht auf einem Insulinmangel, sondern eher auf einer Insulinresistenz beruht. Es erscheint möglich, daß die Schilddrüsenfunktion den Zeitpunkt der maximalen Insulinausschüttung nach Ghucosezufuhr beeinflußt. Nach Glucagoninjektion war der Blutzuckeranstieg bei Hyperthyreose etwa geringer und kürzer als normal. Bei Myxödem trat er zwar zunächst langsamer ein, war aber stärker und hielt länger an als bei den Vergleichspersonen. Der geringere Anstieg bei Hyperthyreose dürfte wahrscheinlich durch den Abbau der Glykogenreserven bedingt sein. Der ILA-Anstieg war sehr stark und anhaltend bei Myxödem und nur mäßig und kurzdauernd bei Thyreotoxikose. Der IRI-Anstieg fiel bei Patienten mit Hypothyreose deutlicher und bei solchen mit Hyperthyreose geringer als normal aus. Die Maximalanstiege traten bei den 3 Kollektiven etwa zur gleichen Zeit ein.

Key-words: Thyrotoxicosis, myxoedema, hyperthyroidism, hypothyroidism, ILA levels, IRI levels, intravenous glucose tolerance test, intravenous glucagon test, insulin resistance, insulinogenic index, glucose disappear ance rate.
The influence of thyroid hormones on glucose metabolism is still being investigated. Early observations of an increased frequency of diabetes $[19,30]$ and abnormal oral glucose tolerance tests in hyperthyroidism [36], of the adverse effect of thyroid hormones in established diabetes [3], as well as of the experimental production of diabetes by the administration of thyroid hormones to partially depancreatized or alloxan treated animals [18], have given rise to the thesis of a diabetogenic role for thyroid hormones.

Some experimental studies have suggested possible mechanisms for this role, such as increased gluconeogenesis [34], increased hepatic glycogenolysis [8], increased insulin degradation [11].

More recently, the frequency of abnormal glucose tolerance tests in hyperthyroidism has been confirmed [20], but the high prevalence of diabetes observed in close relatives of hyperthyroid subjects $[20,22]$ indicates that an increased frequency of diabetes in hyperthyroidism may not be simply a consequence of an excess of thyroid hormones; on the other hand, there is increasing evidence that diabetes is far from being a rare condition in myxoedema $[4,5,29,27,2]$.

Moreover, studies with intravenous glucose tolerance tests have revealed an increased glucose utilization in hyperthyroidism and a decreased utilization in hypothyroidism [12, 21]; therefore, the abnormalities in oral glucose tolerance tests in hyperthyroidism cited above are probably the expression of the increased rate of glucose absorption from the gut [1]. Increased glucose utilization has also been observed in hyperthyroid rats and in their adipose tissue in vitro $[26,23,13]$; it has also been postulated for human adipose tissue in hyperthyroidism [6].

As a result of these investigations, the concept of a diabetogenic action of thyroid hormones has been challenged, and the emerging picture is complex, indicating effects of such hormones on glucose absorption, glucose utilization, glucose production and insulin degradation, all of which may well have divergent influences on blood glucose levels. It is also likely that the clinical conditions, such as severity and duration of the disease, may have an important influence on the results obtained in thyroid patients.
A prerequisite for the thorough understanding of these mechanisms is a knowledge of blood insulin levels in hyper- and hypothyroidism. To date, relatively few studies have appeared on insulin levels in hyperthyroidism, and limited information is available for myxoedema; moreover, data published so far are often conflioting. High values of immunoreactive insulin (IRI) were found by Yalow and Berson [37] in 2 hyperthyroid patients, but normal values were reported by Hales and Hyams [15] in 7 hyperthyroid and 1 hypothyroid subjects. Daweke et al. [9] found normal levels of insulin-like activity (ILA) in 10 cases of hypothyroidism, and significantly reduced values in 10 cases of hyperthyroidism. Spergel et al. [33] in 2 cases of hypothyroidism found an increase in the peak plasma IRI levels following thyroid replacement therapy.

Previous studies from our laboratory showed low fasting ILA levels in hyperthyroidism and high values in hypothyroidism. The pattern of response to oral glucose was different in the two groups, indicating the influence of the different rates of absorption of glucose $[24,25]$. Holdsworth and Besser have recently reported. that correction of hyperthyroidism is associated with a reduction in insulin levels, both fasting and after an oral glucose load, whereas correction of hypothyroidism is not followed by any significant variation of plasma insulin levels [17].

In this study we report investigations on plasma ILA and IRI levels in thyrotoxicosis and primary myxoedema in the fasting state, and after the intravenous administration of glucose or glucagon.

\section{Choice of Patients and Methods}

The present investigations were performed in patients with thyrotoxicosis, in patients with primary myxoedema and in normal control subjects. The number of subjects studied in each test is indicated below.

Diagnosis was established on the basis of clinical examination, thyroid ${ }^{131}$ I uptake, B.M.R., PBI and plasma cholesterol. Normal values for these parameters in our Institute are as follows: thyroid ${ }^{131} \mathrm{I}$ uptake: $10-40 \%$ at $6 \mathrm{~h}$ and $15-60 \%$ at $24 \mathrm{~h} ; \mathrm{B} . \mathrm{M} . \mathrm{R}$. 
$=-10+10 \% ; \mathrm{PBI}=4-8 \mu \mathrm{g} / 100 \mathrm{ml} ;$ cholesterol $=140-220 \mathrm{mg} / 100 \mathrm{ml}$.

All subjects with myxoedema had titers for antithyroglobulin TRC antibodies above 1/250000.

Data on the patients studied are reported in Table 1.

All subjects were hospitalized, and maintained on a diet containing at least $200 \mathrm{~g}$ carbohydrate daily. The patients studied had not received any treatment for their conditions.
10 hyperthyroid, 7 hypothyroid and 9 normal subjects. The $\Delta$-insulin $/ \Delta$-glucose ratio (insulinogenic index) was calculated according to Seltzer et al. [32].

\section{Glucagon Load}

14 hyperthyroid, 10 hypothyroid and 9 normal control subjects received into the cubital vein over two minutes $1 \mathrm{mg}$ of glucagon in $20 \mathrm{ml}$ of $0.85 \% \mathrm{NaCl}$. Blood was drawn in the fasting state, and $5^{\prime}, 10^{\prime}, 15^{\prime}$,

Table 1. Diagnostic data concerning thyrotoxic and myxoedematous subjects.

\begin{tabular}{|c|c|c|c|c|c|c|c|c|c|c|}
\hline \multirow[t]{2}{*}{ Hyperthyroid } & \multirow[t]{2}{*}{ Sex } & \multirow{2}{*}{$\begin{array}{l}\text { Age } \\
\text { yrs }\end{array}$} & \multirow{2}{*}{$\begin{array}{l}\text { Height } \\
\mathrm{cm}\end{array}$} & \multirow{2}{*}{$\begin{array}{l}\text { Weight } \\
\text { kg }\end{array}$} & \multirow{2}{*}{$\begin{array}{l}\text { Over- } \\
\text { weight } \\
\%{ }^{a}\end{array}$} & \multirow{2}{*}{$\begin{array}{l}\text { Cholesterol } \\
\mathrm{mg} / \mathbf{1 0 0} \mathrm{ml}\end{array}$} & \multirow{2}{*}{$\begin{array}{l}\text { P.B.I. } \\
\mu \mathrm{g} / 100 \mathrm{ml}\end{array}$} & \multirow{2}{*}{$\underset{\%}{\text { B. M. R. }}$} & \multicolumn{2}{|c|}{${ }^{131}$ I uptake } \\
\hline & & & & & & & & & $6 \mathrm{~h}$ & $24 \mathrm{~h}$ \\
\hline 1) Giu. & $\mathbf{F}$ & 28 & 161 & 74 & 21 & - & 7.7 & +45 & 83 & 65 \\
\hline 2) Mon. & $\mathrm{F}$ & 63 & 165 & 52 & - & 115 & 14 & $\begin{array}{r}38 \\
+38\end{array}$ & 70 & 63 \\
\hline 3) Rom. & $\mathbf{F}$ & 24 & 162 & 51 & - & 140 & 30 & $\begin{array}{r}78 \\
+7\end{array}$ & 88 & 91 \\
\hline 4) Ang. & $\mathrm{F}$ & 31 & 158 & 45 & - & 160 & 18 & +60 & 86 & 64 \\
\hline 5) Calc. & $\mathbf{F}$ & 47 & 151 & 59 & 3.5 & 195 & 21 & +33 & 84 & 85 \\
\hline 6) Ciarf. & $\mathrm{F}$ & 34 & 147 & 50 & - & 120 & 10.3 & $\begin{array}{r}-50 \\
+\end{array}$ & 85 & 75 \\
\hline 7) Rus. & $\mathbf{F}$ & 30 & 164 & 51 & - & 175 & 14 & -50 & 85 & 72 \\
\hline 8) Man. & $\mathbf{F}$ & 36 & 163 & 62 & 3.3 & 170 & 19 & $\begin{array}{l}+70 \\
-7\end{array}$ & 72 & 73 \\
\hline 9) De R. & $\mathbf{F}$ & 55 & 151 & 47 & - & 230 & - & +53 & 84 & 90 \\
\hline 10) Forn. & $\mathbf{F}$ & 38 & 150 & 52 & 1.9 & 186 & 8 & $\begin{array}{r}+46 \\
\end{array}$ & 90 & 71 \\
\hline 11) Scis. & $\mathrm{M}$ & 55 & 165 & 67 & - & 140 & 9 & +60 & 84 & 70 \\
\hline 12) Mal. & $\mathrm{M}$ & 49 & 171 & 76 & 2.6 & 148 & 10 & $\begin{array}{r}+42 \\
\end{array}$ & 80 & 60 \\
\hline 13) Gav. & $\mathbf{M}$ & 30 & 163 & 53 & - & 104 & 30 & +68 & 79 & 75 \\
\hline 14) Per. & $\mathrm{F}$ & 18 & 164 & 54 & - & - & 14 & +56 & 82 & 71 \\
\hline 15) Monti & $\mathbf{E}$ & 24 & 162 & 63 & 14.6 & - & 11 & +52 & 82 & 75 \\
\hline 16) Cuc. & $\mathrm{F}$ & 43 & 167 & 60 & - & - & 14 & +48 & 85 & 87 \\
\hline \multicolumn{11}{|l|}{ Hypothyroid } \\
\hline 1) Tal. & $\mathrm{F}$ & 50 & 162 & 72 & 10.7 & 355 & 0.9 & -14 & 4 & 7 \\
\hline 2) Cav. & $\mathrm{F}$ & 61 & 147 & 60 & 3.4 & 380 & 1.2 & -10 & 7 & 10 \\
\hline 3) Ant. & $\mathbf{F}$ & 56 & 150 & 55 & - & - & 2.5 & -11 & 22 & 46 \\
\hline 4) Bon. & M & 57 & 176 & 74 & - & 370 & 4.5 & -20 & 0 & 0 \\
\hline 5) $\mathrm{De} P$. & $\mathbf{F}$ & 60 & 149 & 72 & 24.0 & 220 & 1.6 & -20 & 2 & 4 \\
\hline 6) Frat. & $\mathbf{F}$ & 52 & 159 & 78 & 23.9 & 296 & 2.0 & -18 & 3 & 3 \\
\hline 7) Prin. & $\mathrm{F}$ & 36 & 159 & 62 & 6.9 & 196 & 1.0 & -18 & 4 & 6 \\
\hline 8) Cant. & $\mathrm{F}$ & 47 & 158 & 62 & 1.6 & 320 & 1.5 & -14 & 25 & 32 \\
\hline 9) Fin. & $\mathbf{F}$ & 45 & 165 & 84 & 29.0 & 250 & 1.5 & -16 & 2 & 7 \\
\hline
\end{tabular}

a Values calculated on the Geigy Tables (30)

All normal subjects had normal weights according to the Geigy tables [10]. The age range was $25-50$.

\section{Intravenous glucose tolerance test (IVGTT)}

16 hyperthyroid, 8 hypothyroid and 9 normal control subjects received into the cubital vein in $2 \mathrm{~min}$ $25 \mathrm{~g}$ of glucose diluted in $50 \mathrm{ml}$ of distilled water. Blood was drawn in the fasting state, and $10^{\prime}, 15^{\prime}, 30^{\prime}$, $45^{\prime}$ and $60^{\prime}$ from the start of the injection. Blood glucose was assayed and the " $K$ " value was calculated in all subjects according to the method described by Lundbaek [22]. ILA was assayed in 9 hyperthyroid and 7 hypothyroid subjects. ILA values for the patients were compared with basal values obtained in normals in our laboratory; unfortunately, for technical reasons ILA in these subjects could not be assayed after glucose or glucagon injection. IRI was assayed in $30^{\prime}$ and $60^{\prime}$ from the start of the infusion. Blood glucose was assayed in all subjects; ILA was assayed in 7 hyperthyroid and 8 hypothyroid subjects, and IRI was determined in 10 hyperthyroid, 8 hypothyroid and 9 normal subjects.

Blood glucose was determined by the Hoffman method [16], modified for the autoanalyzer; ILA by the fat pad method of Renold et al. [31], modified as described in a previous paper [24]; IRI by the Hales and Randle double antibody immunoassay [14].

\section{Results}

\section{Intravenous glucose tolerance test}

The results are illustrated in Fig. 1 and Table 2.

Differences in blood glucose at individual times were significant between the normal and hyperthyroid group 
at $10^{\prime}, 15^{\prime}$ and $30^{\prime}$; between the normal and hypothyroid group at $30^{\prime}, 45^{\prime}$ and $60^{\prime}$; and between the hyperthyroid and the hypothyroid group at $15^{\prime}, 30^{\prime}, 45^{\prime}$ and $60^{\prime}$.
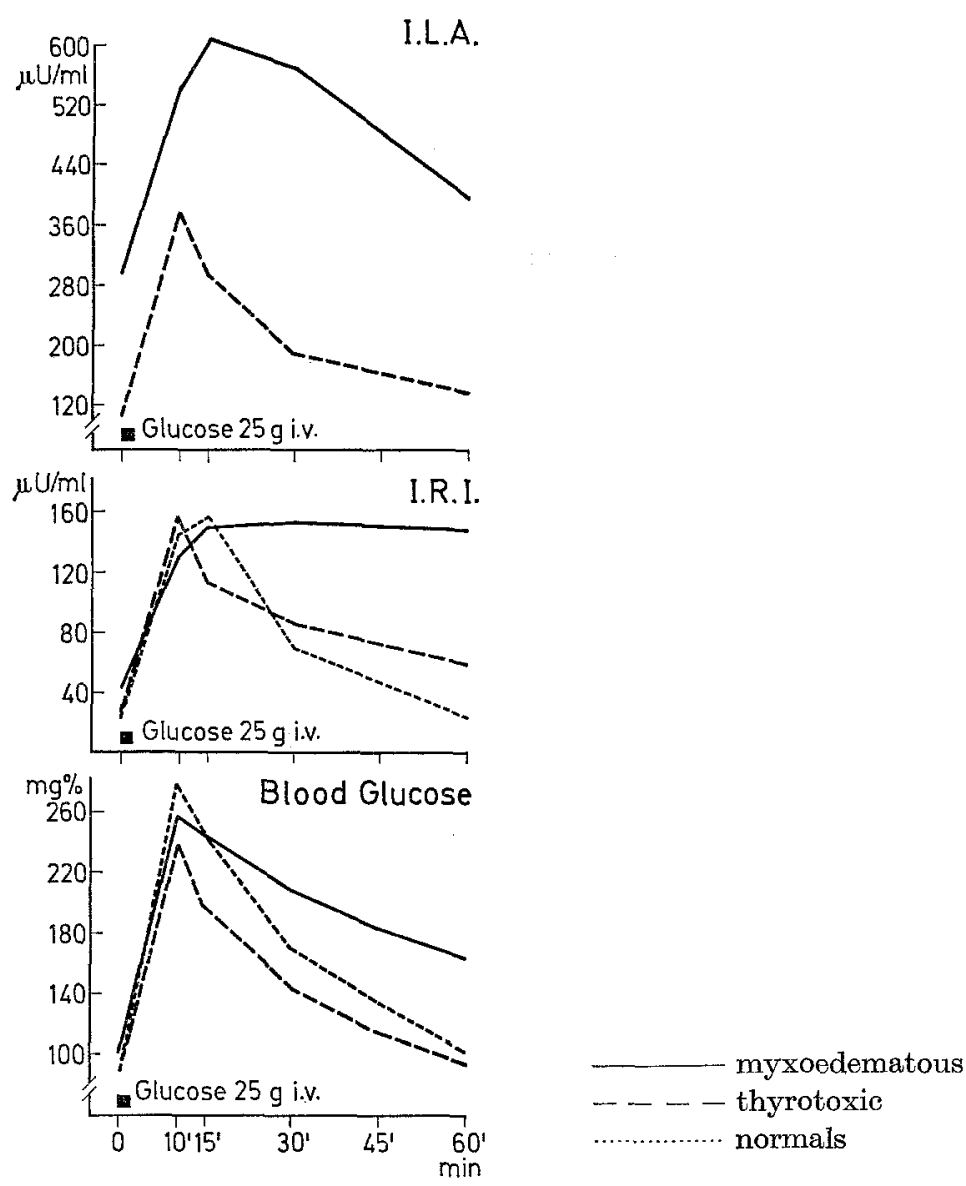

Fig. 1. Insulin-like activity (ILA), immunoreactive insulin (IRI) and blood glucose before and after intravenous administration of glucose $25 \mathrm{~g}$ in hyperthyroid hypothyroid and normal control subjects

Th" rate of glucose disappearance was very near to normal in thyrotoxic, but considerably lower than normal in hypothyroid subjects; and correspondingly, "K" values were significantly lower than normal in the hypothyroid group, but did not differ significantly from normal in the hyperthyroid group.

$I L A$ in the fasting state was significantly higher than normal in myxoedematous, and lower than normal in thyrotoxic subjects. Basal ILA values in our laboratory in 21 normal subjects were $133 \pm 8.2 \mu \mathrm{U} /$ $\mathrm{ml}$. After glucose injection the difference between the two groups of patients was maintained at all times of sampling; peak levels were highest at $10 \mathrm{~min}$ in thyrotoxic and at $15 \mathrm{~min}$ in hypothyroid subjects; differences were significant in the fasting state, and $15^{\prime}, 30^{\prime}$ and $60^{\prime}$ after the injection.

In the fasting state, IRI levels were higher in myxoedematous patients than in either normal or hyper- thyroid subjects; after glucose administration, they increased slightly more rapidly in hyperthyroid than in normal subjects and even more than in hypothyroid subjects; peak levels were observed respectively at 
Table 2. Blood glucose, insulin-like activity (ILA) and immunoreactive insulin (IRI) before and after intravenous administration of glucose $(25 \mathrm{~g})$, in hyperthyroid, hypothyroid and normal control subjects

\begin{tabular}{|c|c|c|c|c|c|c|c|c|}
\hline \multirow[b]{2}{*}{ Time } & \multicolumn{3}{|c|}{ Blood Glucose $(\mathrm{mg} \% \pm \mathrm{SEM})$} & \multicolumn{2}{|c|}{$\mathrm{ILA}(\mu \mathrm{U} / \mathrm{ml} \pm \mathrm{SEM})$} & \multicolumn{3}{|c|}{$\mathrm{IRI}(\mu \mathrm{U} / \mathrm{ml} \pm \mathrm{SEM})$} \\
\hline & $\begin{array}{l}\text { hyper- } \\
\text { thyroid }\end{array}$ & $\begin{array}{l}\text { hypo- } \\
\text { thyroid }\end{array}$ & $\begin{array}{l}\text { normal } \\
\text { control }\end{array}$ & $\begin{array}{l}\text { hyper- } \\
\text { thyroid }\end{array}$ & $\begin{array}{l}\text { hypo- } \\
\text { thyroid }\end{array}$ & $\begin{array}{l}\text { hyper- } \\
\text { thyroid }\end{array}$ & $\begin{array}{l}\text { hypo- } \\
\text { thyroid }\end{array}$ & $\begin{array}{l}\text { normal } \\
\text { control }\end{array}$ \\
\hline $0^{\prime}$ & $88 \pm 3$ & $101 \pm 10$ & $88 \pm 3$ & $106 \pm 14$ & $298 \pm 29$ & $30 \pm 5$ & $43 \pm 6$ & $24 \pm$ \\
\hline $10^{\prime}$ & $240 \pm 7$ & $256 \pm 13$ & $280 \pm 15$ & $375 \pm 72$ & $542 \div 129$ & $157+26$ & $131 \pm 13$ & $145 \pm 41$ \\
\hline $15^{\prime}$ & $198 \pm$ & $244 \pm 10$ & $245 \pm 12$ & $292 \pm 56$ & $608 \pm 118$ & $113 \pm 17$ & $149 \pm 11$ & $157 \pm 49$ \\
\hline $30^{\prime}$ & $145 \pm 8$ & $209 \pm 14$ & $171 \pm 8$ & $187 \pm 25$ & $569 \pm 134$ & $86 \pm 19$ & $152 \pm 17$ & $70 \pm 16$ \\
\hline $45^{\prime}$ & $116 \pm 10$ & $184 \pm 11$ & $136 \pm 10$ & -- & - & - & -- & -- \\
\hline $60^{\prime}$ & $96 \pm 8$ & $163 \pm 14$ & $103 \pm 5$ & $138 \pm 17$ & $396 \pm$ & $59 \pm 11$ & $147 \pm 16$ & $24 \pm$ \\
\hline "k" value & $2.07 \pm 0.26$ & $0.73 \pm 0.15$ & $1.83 \pm 0.14$ & & & & & \\
\hline
\end{tabular}

" $t$ " test:

\begin{tabular}{|c|c|c|c|c|c|c|c|}
\hline & \multicolumn{3}{|c|}{ Blood Glucose } & ILA & \multicolumn{3}{|c|}{ IRI } \\
\hline Time & $\begin{array}{l}\text { control/ } \\
\text { hyper- } \\
\text { thyroid }\end{array}$ & $\begin{array}{l}\text { control/ } \\
\text { hypo- } \\
\text { thyroid }\end{array}$ & $\begin{array}{l}\text { hyper- } \\
\text { thyroid/ } \\
\text { hypothyroid }\end{array}$ & $\begin{array}{l}\text { hyperthyroid/ } \\
\text { hypothyroid }\end{array}$ & $\begin{array}{l}\text { control/ } \\
\text { hyper- } \\
\text { thyroid }\end{array}$ & $\begin{array}{l}\text { control/ } \\
\text { hypo- } \\
\text { thyroid }\end{array}$ & $\begin{array}{l}\text { hyper- } \\
\text { thyroid/ } \\
\text { hypothyroid }\end{array}$ \\
\hline $0^{\prime}$ & NS & NS & NS & $p<0.001$ & NS & $p<0.02$ & $\mathrm{NS}$ \\
\hline $10^{\prime}$ & $p<0.01$ & NS & NS & NS & NS & NS & NS \\
\hline $15^{\prime}$ & $p<0.002$ & NS & $p<0.02$ & $p<0.05$ & NS & $\mathrm{NS}$ & $\mathrm{NS}$ \\
\hline $30^{\prime}$ & $p<0.05$ & $p<0.01$ & $p<0.005$ & $p<0.02$ & NS & $p<0.01$ & $p<0.05$ \\
\hline $45^{\prime}$ & NS & $p<0.02$ & $p<0.002$ & - & - & - & - \\
\hline $60^{\prime}$ & NS & $p<0.0005$ & $p<0.0005$ & $p<0.01$ & $p<0.01$ & $p<0.001$ & $p<0.001$ \\
\hline
\end{tabular}

Table 3. Intravenous glucose tolerance test. Serum insulin blood glucose relationships

Insulinogenic index $=\frac{\Delta \text { insulin } \frac{(\mu \mathrm{U} / \mathrm{ml})}{\Delta \text { Glucose }}(\mathrm{mg} \%)}{(\mathrm{m} / \mathrm{m}}$

\begin{tabular}{llllll}
\hline \multicolumn{7}{c}{ Time (min) } & & & \\
\hline \multirow{2}{*}{ Thyrotoxic } & 10 & 15 & 30 & 60 \\
& Mean & 0.91 & 0.85 & 0.83 & 0.80 \\
& \pm SEM & 0.22 & 0.25 & 0.27 & 0.28 \\
\hline Myxoedematous Mean & 0.47 & 0.67 & 0.84 & 1.61 \\
& \pm SEM & 0.19 & $\mathbf{0 . 1 5}$ & 0.12 & 0.30 \\
\hline Normals & Mean & 0.81 & 0.96 & 0.87 & 0.59 \\
& \pm SEM & 0.27 & 0.29 & 0.26 & 0.20 \\
\hline
\end{tabular}

The only significant difference was observed between the myxoedema group and the others at $60^{\prime}$

\section{Glucagon load}

Results are illustrated in Fig. 2 and Table 4.

In thyrotoxic subjects the blood glucose increase after glucagon was significantly lower and shorter than normal. In hypothyroid patients the increase was initially somewhat slower than in normal; however, it was definitely more sustained, with high values persisting at $60^{\prime}$. Differences between hyperthyroid and normal were significant at $5^{\prime}, 10^{\prime}, 15^{\prime}, 30^{\prime}$; between hypothyroid and normal at $60^{\prime}$; and between thyrotoxic and hypothyroid at $30^{\prime}$ and $60^{\prime} . I L A$ levels in the hyperthyroid were lower than in the hypothyroid subjects in the fasting state, and at all times after injection; in the hypothyroid group there was a very slow decline from the peak level, so that at $60^{\prime}$ the values were still higher than in the fasting state. Differences between the two groups of patients were significant at all times.
IRI levels in the fasting state were higher in hypothyroid than in both hyperthyroid and normal subjects. After injection there was a sharp increase in all groups; peak levels (all at $5^{\prime}$ ) were higher in myxoedema and lower in hyperthyroidism.

Immediately after the peak, the decline of IRI levels was more rapid than normal in hyperthyroid and slower in hypothyroid subjects. At $60^{\prime}$ the IRI levels returned almost to fasting values in both the hyperthyroid and normal, whereas in the hypothyroid group the mean value was still above $120 \mu \mathrm{U} / \mathrm{ml}$. Differences between the hyper- and hypothyroid group were significant in the fasting state, and at $10^{\prime}$ and $60^{\prime}$; those between hyperthyroid and normal at $10^{\prime}$; and those between myxoedema and normal in the fasting state and after $60^{\prime}$.

\section{Comment}

In the fasting state, ILA levels were significantly reduced in thyrotoxicosis, as already observed by Daweke et al. [9], and increased in myxoedema, when compared with normal; this confirms our previous findings [7]. Since, in the present study, fasting IRI levels appeared to be normal in hyperthyroidism, thus confirming Hales and Hyams data [15], and higher than normal in hypothyroidism, it is possible that some factor other than insulin levels influences the ILA findings in the former condition. It seems unlikely that this can be due to a direct influence of different thyroid hormone levels on the adipose tissue. Further investigation is necessary to elucidate this point. Slight discrepancies between the ILA and IRI levels have also been found during the glucose and glucagon 
tests, but the general pattern of behaviour was broadly the same with the two methods.

The high insulin levels in myxoedema may have been due to reduced catabolism of insulin in this disease, since it has been observed that thyroid hormones definite difference was seen at $60^{\prime}$. At this time the ratio was significantly higher in the myxoedema group.

The low " $K$ " values in myxoedema were evidently not due to deficiency of insulin, since the total insulin output during the time periods considered seemed to

Table 4. Blood glucose, insulin-like activity (ILA) and immunoreactive insulin (IRI) before and after intravenous administration of glucagon (1 mg) in hyperthyroid, hypothyroid and normal control subjects

\begin{tabular}{|c|c|c|c|c|c|c|c|c|}
\hline \multirow[b]{2}{*}{$\begin{array}{l}\text { time } \\
\text { min }\end{array}$} & \multicolumn{3}{|c|}{ Blood Glucose (mg\% \pm SEM) } & \multicolumn{2}{|c|}{$\mathrm{ILA}(\mu \mathrm{U} / \mathrm{ml} \pm \mathrm{SEM})$} & \multicolumn{3}{|c|}{$\operatorname{IRI}(\mu \mathrm{U} / \mathrm{ml} \pm \mathrm{SEM})$} \\
\hline & $\begin{array}{l}\text { hyper- } \\
\text { thyroid }\end{array}$ & $\begin{array}{l}\text { hypo- } \\
\text { thyroid }\end{array}$ & $\begin{array}{l}\text { normal } \\
\text { control }\end{array}$ & $\begin{array}{l}\text { hyper- } \\
\text { thyroid }\end{array}$ & $\begin{array}{l}\text { hypo- } \\
\text { thyroid }\end{array}$ & $\begin{array}{l}\text { hyper- } \\
\text { thyroid }\end{array}$ & $\begin{array}{l}\text { hypo- } \\
\text { thyroid }\end{array}$ & $\begin{array}{l}\text { normal } \\
\text { control }\end{array}$ \\
\hline$\overline{0^{\prime}}$ & $84 \pm 4$ & $83 \pm 3$ & 82 士 5 & $105 \pm 11$ & $227 \pm 28$ & $26 \pm 4$ & $48 \pm 8$ & $25 \pm 3$ \\
\hline $5^{\prime}$ & 97. & $104 \perp 10$ & $118+12$ & $272+52$ & $554+102$ & $199+32$ & $266+27$ & $233+47$ \\
\hline $10^{\prime}$ & $105 \pm 5$ & $121 \pm 11$ & $125 \pm 8$ & $244 \pm 41$ & $551 \pm 70$ & $149 \pm 23$ & $262 \pm 32$ & $222 \pm 39$ \\
\hline $15^{\prime}$ & $113 \pm 5$ & $127+11$ & $134 \pm$ & $197 \pm 36$ & $547 \div$ & $132+20$ & $186+22$ & $167+25$ \\
\hline $30^{\prime}$ & $102 \pm 6$ & $156 \pm 9$ & $144 \pm 10$ & $\ldots$ & & - & - & - \\
\hline $60^{\prime}$ & $82 \pm 4$ & $130 \pm 11$ & $89 \pm 8$ & $160 \pm 16$ & $557 \pm 107$ & $41 \pm 10$ & $122+18$ & $41 \pm$ \\
\hline
\end{tabular}

"to" test:

\begin{tabular}{|c|c|c|c|c|c|c|c|}
\hline $\begin{array}{l}\operatorname{time} \\
\text { min }\end{array}$ & $\begin{array}{l}\text { control/ } \\
\text { hyper- } \\
\text { thyroid }\end{array}$ & $\begin{array}{l}\text { lood Glucos } \\
\text { control/ } \\
\text { hypo- } \\
\text { thyroid }\end{array}$ & $\begin{array}{l}\text { hyperthy- } \\
\text { roid/hypo- } \\
\text { thyroid }\end{array}$ & $\begin{array}{l}\text { ILA } \\
\text { hyperthy- } \\
\text { roid/hypo- } \\
\text { thyroid }\end{array}$ & $\begin{array}{l}\text { control/ } \\
\text { hyper- } \\
\text { thyroid }\end{array}$ & $\begin{array}{l}\text { IRI } \\
\text { control/ } \\
\text { hypo- } \\
\text { thyroid }\end{array}$ & $\begin{array}{l}\text { hyperthyroid/ } \\
\text { hypothyroid }\end{array}$ \\
\hline $0^{\prime}$ & NS & $\mathrm{NS}$ & NS & $p<0.01$ & $\overline{\mathrm{NS}}$ & $p<0.02$ & $p<0.05$ \\
\hline $5^{\prime}$ & $p<0.01$ & NS & NS & $p<0.01$ & NS & NS & NS \\
\hline $10^{\prime}$ & $p<0.05$ & NS & NS & $p<0.01$ & $p<0.02$ & NS & $p<0.05$ \\
\hline $15^{\prime}$ & $p<0.05$ & NS & NS & $p<0.01$ & NS & NS & NS \\
\hline $30^{\prime}$ & $p<0.01$ & NS & $p<0.001$ & - & - & 一 & - \\
\hline $60^{\prime}$ & NS & $p<0.02$ & $p<0.001$ & $p<0.01$ & NS & $p<0.001$ & $p<0.001$ \\
\hline
\end{tabular}

increase insulin degradation [11]. They might also be connected with the reduced glucose utilization, as discussed below.

After intravenous glucose administration, the rate of glucose disappearance in hyperthyroidism was rather similar to normal, whereas it was markedly and significantly reduced in myxoedema; the " $K$ " values observed in this latter condition were comparable with those commonly observed in diabetics. Therefore, it seems likely that glucose utilization is reduced in myxoedema, as observed by Lamberg [21] and by Trisotto et al. [35].

The increment in immunoreactive insulin reached a peak in the hyperthyroid group before the normal group, and in the latter before the myxoedema group; however, the differences were not significant. It is possible that in our patients the highest peak may not have been observed, as our first determination was at $10 \mathrm{~min}$, and the peak insulin concentration may have occurred before this time; this is more likely in the case of the hyperthyroid group, which showed the maximal level in the first sample.

The determination of the insulinogenic index according to Seltzer et al. [32] (Table 3) did not reveal any significant differences in the first $30^{\prime}$ after glucose administration; but the mean values indicated a slower increase in the myxoedema group. Therefore, it may be worth while to investigate further the possibility that the immediate insulinogenic response to the intravenous glucose load is reduced in myxoedema. A more be higher than normal; therefore, it seems likely that there is a resistance to insulin in this condition.

The recent investigations by Holdsworth and Besser [17] are not comparable with ours, since these authors studied blood glucose and immunoreactive insulin in response to an oral glucose load; however, their data seem to indicate, in agreement with ours, that there is insulin resistance in myxoedema. On the other hand, the findings of the same authors do not agree with our finding that insulin levels are greater than normal in this condition. This may be due to some difference in the selection of patients, as in our experience of primary myxoedema [2] the frequency of abnormal oral glucose tolerance tests is higher than that observed by Holdsworth and Besser [17].

After glucagon injection the small and short-lasting rise of blood glucose levels in hyperthyroidism is consistent with the reduction of glycogen stores in this condition; and the persistance of elevated blood glucose levels at sixty minutes in myxoedema can be explained on the basis of reduced glucose utilization, as observed in the IVGTT.

The peak insulin level was observed in the first sample $\left(5^{\prime}\right)$ following administration of glucagon in all three groups. This fact may indicate that the direct insulinogenic effect of glucagon is not influenced by thyroid function, but further work is necessary to clarify this point. After the peak there was a sharp fall of insulin levels in hyperthyroidism, and a slower decline in the other two groups; this was probably due 
to the more modest increment of blood glucose in hyperthyroidism; in myxoedema, the persistence of elevated insulin levels at sixty minutes may have been due to the persistent hyperglycemia.

Some of the differences observed might be related to differences in weight among the various groups of subjects; it is very difficult to have a series of hyperthyroid and myxoedematous patients that are matched for weight. However, our myxoedematous patients were not grossly overweight.

Research is being carried out to investigate the effect of treatment on the behaviour of blood glucose and insulin in primary myxoedema.

\section{References}

1. Althausen, T.L., Stockholm, M.: Influence of thyroid gland on absorption in digestive tract. Amer. J. Physiol. 123, 577-588 (1938).

2. Andreani, D.: Glucose metabolism in thyroid disease. In press.

3. Balfour, W.M., Sprague, R.G.: Association of diabetes mellitus and disorders of anterior pituitary, thyroid and adrenal cortex. Amer. J. Med. 7, 596-608 (1949).

4. Baron, D.N.: Hyperthyroidism and diabetes mellitus. Lancet 1955 II, $796-798$.

5. Bloomer, H.A., Kyle, L.H.: Myxœdema (80 cases). Arch. intern. Med. 104, 234-241 (1959).

6. Butterfield, W.J.H., Whichelow, M.J.: Are thyroid hormones diabetogenic? Metabolism 13, 620-628 (1964).

7. Cassano, C., Androani, D., Menzinger, G.. Pinchera, A., Fallucea, F., Aliberti, G., de Santis, R., Tamburrano, G.: Thyréopathies et diabète. Journeies Annuelles de diabétologie de l'Hôtel-Dieu, 1967, p. 229.

8. Cramer, W., Krause, R.A.: Carbohydrate metabolism in its relation to the thyroid gland; the effect of thyroid feeding on the glycogen content of the liver and on the nitrogen distribution in the urine. Proc. roy. Soc, (London) B 86, 550 (1943).

9. Daweke, H., Oberdisse, K., Reinwein, D., Bethge, F., Schilling, W.: Insulinähnliche Aktivität und Glucosetoleranz bei Hyperthyreose und Myxoedem. Diabetologia 1, 78- 79 (1965).

10. Documenta Geigy: Tables scientifiques - VI ed. p. 634. Basle: Geigy, 1963.

11. Elgee, M.J., Williams, R.W.: Effect of thyroid function on insulin $\mathrm{I}^{\mathbf{1 3 1}}$ degradation. Amer. J. Physiol. $180,13-15(1955)$.

12. Eilrick, H.G., Hlad, C.J., Arai, Y.: Influence of thyroid function on carbohydrate metabolism and a new method for assessing response to insulin. J. clin. Endocr. 21, 387-400 (1961).

13. Hagen, G.H.: Effect of insulin on the metabolism of adipose tissue from hyperthyroid rats. J. biol. Chem. 235, 2600-2602 (1960).

14. Hales, C.N., Randle, P.J.: Immunoassay of insulin with insulin-antibody precipitate. Biochem. J. 88, $137-146(1963)$.

15. - Hyams, D.E.: Plasma concentrations of glucose, non-esterified fatty acid, and insulin during oral glucose-tolerance test in thyrotoxicosis. Lancet $\mathbf{1 9 6 4}$ II, $69-70$.

16. Hoffman, W.S.: A rapid photoelectric method for the determination of glucose in blood and urine. J. biol. Chem. 120, $51-55$ (1937).

17. Holdsworth, C.D., Besser, G.M. : Influence of gastric emptying-rate and of insulin response on oral glucose tolerance in thyroid disease. Lancet $1968 \mathrm{II}, 700-703$.

18. Houssay, B.A.: The action of the thyroid on diabetes. Recent Progr. Hormone Res. 2, 277-291 (1948).

19. Joslin, E.P., Lahey, F.H.: Diabetes and hyperthyroidism. Amer. J. med. Sei. 176, 1-22 (1928).

20. Kreines, K., Jett, M., Knowles, H.C.: Observations in hyperthyroidism of abnormal glucose tolerance and other traits related to diabetes mellitus. Diabetes 14, $740-744(1965)$.

21. Lamberg, B.A.: Glucose metabolism in thyroid diseases. In Cassano C. and Andreoli M.: Current topics in thyroid research. Proc. 5th Int. Thyroid Conference, pag. 1074. New York: Acad. Press., 1965.

22. Lundbaek, K.: Intravenous glucose tolerance as a tool in definition and diagnosis of diabetes mellitus. Brit. Med. J. 1962 I, 1507-1513.

23. Macho, L.: Influence of endocrine glands on carbohydrate metabolism : II the effect of thyroid gland on the insulin sensitivity in rabbits. Arch. int. Physiol. 67, 4 (1959).

24. Menzinger, G., Fallucca, F., Pellegrinotti, A.: Attività insulinosimile del siero nell'ipertiroidismo. Folia endocr. 18, 691-701 (1965).

25. - - Aliberti, G., Tamburrano, G. Andreoli, M.: Comportamento dell'attivita insulinosimile del siero in risposta al carico di glucosio e di glucagone nell'ipotiroidismo e nell'ipertiroidismo. Folia endocr. 21, $104-120(1968)$.

26. Mirsky, A., Broh-Kahn, R.H.: The effect of experimental hyperthyroidism on carbohydrate metabolism. Amer. J. Physiol. 117, 6-12 (1936).

27. Papalia, D., Vigneri, R., Casale, P., Motta, L.: La funzione tiroidea nel diabete mellito. Folia endocr. 20, 94-107 (1967).

28. Perlman, L. V.: Familial incidence of diabetes in hyperthyroidism. Ann. int. Med. 55, 796-799 (1961).

29. Pirart, J.: Action diabétogène de la thyroide. Ann. Endocr. 62, 27-42 (1965).

30. Regan, J.F., Wilder, R.M.: Hyperthyroidism and diabetes. Arch. intern. Med. 65, 1116-1122 (1940).

31. Renold, A.E., Martin, D.B., Dagenais, Y.M., Steinke, J., Nickerson, R.G., Sheps, M.C.: Measurement of small quantities of insulin like activity using rat adipose tissue. J. clin. Invest. 39, 1487-1498 (1960).

32. Seltzer, H.S., Allen, W.E., Herron, A.L., Brennan, M.T.: Insulin secretion in response to glycemic stimulus: relation to delayed initial release to carbohydrate intolerance in mild diabetes mellitus. J. clin. Invest. 46, 323-335 (1967).

33. Spergel, G., Levy, L., Goldner, M.: The impaired carbohydrate metabolism of thyroid disease. Dia. betes 17, Suppl. 1, 345 (1968).

34. Soskin, S., Levine, R., Heller, R. E.: Role of thyroid in carbohydrate disturbance which follows hypophysectomy. Amer. J. Physiol. 125, 220-226 (1939).

35. Trisotto, A., Federspil, G., Scandellari, C., Frezzato, S., Lazzatin, M.: Disfunzioni tiroidee e metabolismo del glucosio. Metabolismo 4, 273-286 (1968).

36. Wilder, R.M.: Clinical diabetes mellitus and hyperinsulinism. Philadelphia and London: W.B. Saunders Company, 1940.

37. Yalow, R.S., Berson, S.A.: Immunoassay of endogenous plasma insulin in man. J. clin. Invest. 39, $1157-1175$ (1960).

Dr. D. Andreani

II. Clinica Medica dell'Università

di Roma

I-00100 Roma

Policlinico Umberto I 